\title{
本州 四国連絡橋の規模と防食塗装について
}

\section{ま えがき}

本州と四国を橋で結ぼうと考えたのはいつごろからで あららか。

昭和 45 年 7 月, この架橋を実施する機関として, 本州 四国連絡橋公団が設立された。当公団はこれまで，建設 省・日本道路公団・日本国有鉄道ならびに日本鉄道建設 公団が行なった調査 ${ }^{123)}$ のすべてを引継ざ，さらに工事 実施のための諸作業を進めている。

本文では本四架橋の概要と特に防食関係の現況につい て御報告したいと思ら。

\section{1. 本四架橋の概 要}

四国と本州を陸上交通路で直結することは，瀬戸内沿 岸の人々の長い間の夢でもあった。このことは単に四 国，あるいは西日本発展の基盤を造るのみならず，その 効果は日本全体に及ぶと推算されている。

試みに，たとえば宇野〜高松間の連絡船に乗ってみれ ば招わかりになるであろら。瀬戸内海を東西に走る大型 船の数々，そして四国と本州を直接結んで南北に走る船 の多さを。昭和 65 年には, 本四橋だけの通過量が 1 日 当たり旅客 37 万人, 貨物 21 万トン, 自動車 4 万台と 推定されている4)。(図-1)

本四架橋は次の 3 ルートであり, 本四公団では建設・ 運輸両省の指示に従ってこの 3 ルートについて調査を進 めている。

イ）神戸〜鳴門ルート一土木学会報告書) 飞従って Aルート呼ばれている。神戸から明石海陕を渡り, 淡路 島を通り, 鳴門海陕を渡り, 鳴門德島に至る。国道 28 号 線扮よび鉄道を通す。

昭和 47.5 .1 受理

On the Honshu-Shikoku Bridges

Ikuo FUJII

* 本州四国連絡橋公団設計第 2 課。(現) 児島調查事務 所一岡山県倉敷市児島味野児島産業会館 4 階 東京都港区芝西久保城山町 1 第 22 森ビル 6 階
藤 井 郁 夫*

表-1 本四連絡橋ルート別延長・工費 （建設・運輸両省による）

\begin{tabular}{|c|c|c|c|c|c|c|}
\hline \multicolumn{3}{|c|}{ ルート名 } & 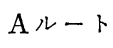 & 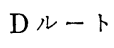 & $\mathrm{E} ル ー ト$ & 合 計 \\
\hline 延 & \multicolumn{2}{|c|}{ 海陕部 } & 6.9 & 9.5 & 9.9 & 26.3 \\
\hline \multirow{3}{*}{$\begin{array}{l}\text { 長 } \\
\text { 粰 }\end{array}$} & \multirow{2}{*}{$\begin{array}{l}\text { 陸 } \\
\text { 上 } \\
\text { 部 }\end{array}$} & 道路 & 77.6 & 31.2 & 69.5 & 178. 3 \\
\hline & & 鉄道 & 77 & 32.5 & - & 109. 5 \\
\hline & \multicolumn{2}{|c|}{ 合 計 } & 161.5 & 73.2 & 79.4 & 314.1 \\
\hline \multirow{2}{*}{$\frac{\text { 工 }}{\text { 費 }}$} & \multicolumn{2}{|c|}{ 海峡部 } & 2,452 & 1,747 & 1,013 & 5,212 \\
\hline & & 道路 & 608 & 390 & 465 & 1,463 \\
\hline \multirow{2}{*}{$\begin{array}{l}\text { 意 } \\
\text { 円 }\end{array}$} & & 鉄道 & 668 & 414 & - & 1,082 \\
\hline & 合 & 計 & 3,728 & 2,551 & 1,478 & 7,757 \\
\hline
\end{tabular}

尸）児島〜坂出ルート—いわゆるDルートと呼ばれ ている。岡山県倉敷市児島付近より島づたいに走り, 香 川県坂出市番ノ州に上陸する。国道 30 号線と鉄道を通 す。

八）尾道〜今治ルート—いわゆる 317 号線であり, 尾道から, 向島, 因島, 生口島, 大三 島, 伯方島, 大島を通って今治に至る。

これら 3 ルートの延長, 工費を 表-1 に示す6,7。 本四架橋にとって，その技術的検討を行ない，その可 能性を明らかにした土木学会報告 書 ${ }^{5}$ の意義は大きい。 同報告書を中心に本四架橋の規模についてみると次のよ らである。

現在，世界最大の吊橋は米国のベラザノナロース橋で あるが，本四橋が竣功するとこれを恃るかに越える規模 となり，かつ世界 20 位までのらちの 9 橋までが本四橋 となる。主要吊橋の塔の高さを図-2 に示す。吊橋以外飞 ついても，たとえばトラス橋では現在世界最大はケへッ ク橋のスパン $548 \mathrm{~m}$ であるが，本四では $500 \mathrm{~m}$ 級のトラ ス橋が 2 橋計画されている。しかも本四橋は他国に比し て水深・潮流などの自然条件がきびしい。たとえば諸外 国の吊橋はほとんどが $30 \sim 40 \mathrm{~m} /$ 秒程度の風速に対して 設計されているが，本四橋は $60 \sim 70 \mathrm{~m} /$ 秒以上の風速に 


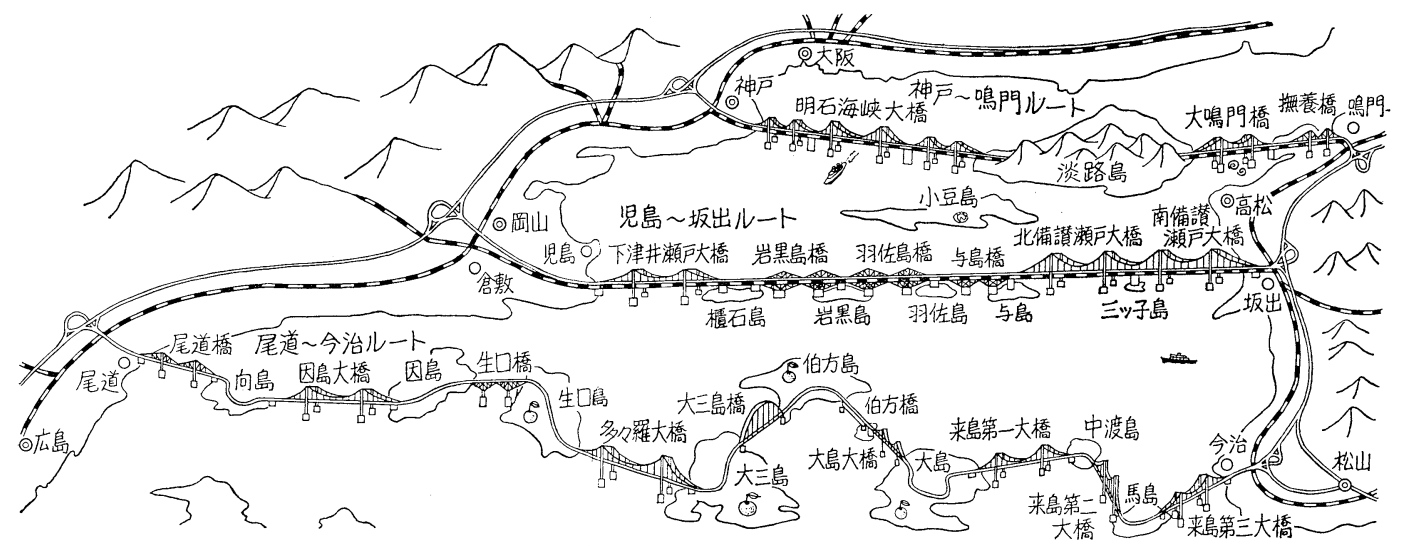

図-1 本四架橋のルート

表-2 1985 年に打ける世界長大支間吊橋の予想

\begin{tabular}{|c|c|c|c|}
\hline 順位 & 橋 & 国 & \begin{tabular}{|} 
中央支間 \\
$(\mathrm{m})$
\end{tabular} \\
\hline 1 & 明石海陕大橋 & 本 & 1,517 \\
\hline 2 & ハンバー 橋 & イギリス & 1,396 \\
\hline 3 & ベラザノ・ナロウズ橋 & アメリカ & 1,298 \\
\hline 4 & ゴールデン・ゲート橋 & "1 & 1,280 \\
\hline 5 & マ キ ノ 橋 & " & 1,158 \\
\hline 6 & 南備讃瀬戸大橋 & 本 & 1,110 \\
\hline 7 & ボスポラス橋 & $\begin{array}{ll}1 & =\end{array}$ & 1,074 \\
\hline 8 & ジョージ・ワシントン橋 & アメリカ & 1,067 \\
\hline 9 & サラザール橋 & ポルトガル & 1,013 \\
\hline 10 & 来島第 3 大橋 & 本 & 1,008 \\
\hline 11 & フォース道路橋 & イギリス & 1,006 \\
\hline 12 & セバーン橋 & "I & 988 \\
\hline 13 & 下津井瀬戸大橋 & 本 & 909 \\
\hline 14 & 因 島 大 橋 & $\prime \prime$ & 907 \\
\hline 15 & 多々羅大橋 & $\prime \prime$ & 887 \\
\hline 16 & 北備濽瀬戸大橋 & " & 869 \\
\hline 17 & 来島第 1 大橋 & 11 & 867 \\
\hline 18 & ニュー・タュマ・ナロウズ橋 & アメリカ & 853 \\
\hline 19 & 大 鳴 門 橋 & 日本 & 808 \\
\hline 20 & 関 門 橋 & $\prime \prime$ & 712 \\
\hline
\end{tabular}

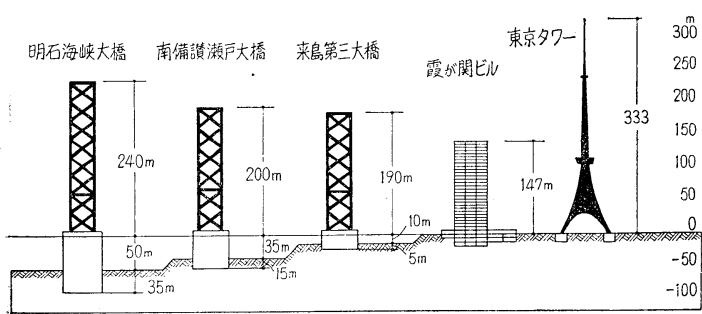

図-2 主 要 塔の高さ
耐えなければならない。また日本は世界有数の地震国で もある。

ここで表-1 からわかるように, 本四架橋全ルート延長 $314 \mathrm{~km}$ のらち, いわゆる海上部は約 $26 \mathrm{~km}$ であり, 取 り付け部といわれる陸上部が, 道路 $178 \mathrm{~km}$, 鉄道 $110 \mathrm{~km}$ に及ぶ。これは名神高速道路が $180 \mathrm{~km}$, 新幹線大阪〜 岡山間が $161 \mathrm{~km}$ であることからもとの事業規模が推定 されよう。

本四架橋の事業費は表-1のように推定されている ${ }^{6,7)}$ 。 この巨額の資金は政府和よび関係地方公共団体の出資金 と, 本州四国連絡橋公団債とによって調達し, 自動車通 行料・鉄道利用料などで償還することとなって扣り， 20 年〜30 年前後で償還し得ると推定されている4)。

な特 45 年度执よび 46 年度の出資金の合計は, 政府 7 億円, 地方公共団体が 5 億円で, その出資地方公共団 体は，大阪府・兵庫・岡山・広島・徳島・香川・愛媛・ 高知の各県衫よび大阪・神戸の両市であった。

本四公団としては, 現在神戸, 児島および尾道に調查 事務所を置き, 昭和 60 年完成をめざし, 48 年度には 3 ルートそれぞれ着工できるように調査を進めている。

本四公団の 46 年度予算は 57 億円であり，47 年度は 100 億円を越える。

\section{2. 防食調查}

\section{1 調查経過}

直接に本四橋を対象とした調査はこれまで建設省土木 研究所括よび国鉄技術研究所を中心に行なわれてきた。 その打もなるのは次のと叔りである。

イ）淡路島松帆門よび鳴門市大毛島での現地暴露を 中心とする各種塗装系の比較調査8)

口）大毛島执よび神戸市垂水での現地暴露を中心とす 
る油性サビ止めーフダル酸系塗装の調査 ${ }^{9,10)}$

八）組成・成分の明らかな塗料を用いて，览島での現 地暴露を中心とする各種塗装系扤よび方法などの調査 ${ }^{3)}$

二) 高松 (現在は児島) のイカダ上での現地暴露を中 心とする重塗装あるいは金属被覆などの調査 ${ }^{3)}$

ホ）岩屋沖での現地暴露を中心とする主として海面付 近の鋼材の防食調査 ${ }^{11}$

へ）現地暴露を含む鋼材の腐食疲労調査 ${ }^{3 \sim 12}$

本四公団発足後も, 上記両研究所に委託あるいは御指 導を頂き，これらの調査を引続き進めている。

さらに, 昭和 46 年度より土木学会に委託した「本州 四国連絡橋鋼上部構造研究小委員会」内に, 塗装分科会 を置さ，佐藤靖博士に主查を，橋本達知，蒔田実，森芳 徳の諸氏に委員を扣願いして，必要に応じて有識者の御 出席を扣願いしたり，現地調査を行ならなどにより総合 的な検討を行なっている。

\section{2 本四橋の塗装}

1）本四架橋全体の上部工重鋼は表-3 のように推定

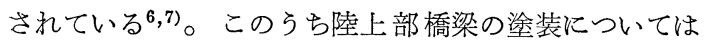
これまでも各方面で調査が進められているので, 以下主 として海峡部上部工を対象にすることとする。

2）架橋地点は図-1に示すように東は明石から西は 今治まで広がる。瀬戸内海は近年污濁が著しく，しかも 重化学工場が散在するため一概にはいえないが, 調査資 料からみると，垂水では亜硫酸ガスが $1.12 \mathrm{mg} /$ 日/1000 $\mathrm{cm}^{3} \mathrm{PbO}_{2}$ ，モール法による海塩粒子量は $1.23 \mathrm{ppm} /$ 月/ $100 \mathrm{~cm}^{2}$ であり, 雨水分析による $\mathrm{SO}_{4}$ 打よび $\mathrm{Cl}$ 降塩量

表-3 上部工鋼重

(単位 1,000 トン)

\begin{tabular}{|c|c|c|c|c|c|}
\hline & & $A ル ー ト$ & $\mathrm{D} ル ー ト$ & $\mathrm{E} ル ー ト$ & 合 \\
\hline 海 陕 & 部 & 228 & 201 & 226 & 655 \\
\hline 陸 上 & 部 & 100 & 100 & 48 & 248 \\
\hline 合 & 計 & 328 & 301 & 274 & 903 \\
\hline
\end{tabular}

の全降塩量に対する比は, 児島では $\mathrm{SO}_{4}$ が $0.16, \mathrm{Cl}$ が 0.37 であった。いずれる海塩粒子の影響を受けてい るのは当然であるが，その泳か、，川崎あるいは東京ほ ぞではないが工場地帯的な大気污染をかなり受けている といえる。

3）現地に暴露した無塗装鋼板の重量減より推定した 平均侵食深さは 2 年間で $0.2 \mathrm{~mm}, 5$ 年間で $0.7 \mathrm{~mm}$ 程 度であった。試料数の多い 2 年間暴露での值では鋼材の 強さ，普通鋼，耐候性鋼による差は認められなかった。

$7.4 \mathrm{~mm}$ 厚鋼板を現地暴露したのちの引張強さは， 5 年間で 5〜15\% 減少している。(図-3）

列車のよらに重い荷重を繰り返して負担する橋梁部材 にとっては, 鋼材の疲れ強さが非常に重要である。現地 暴露をした鋼材 $(\phi 10 \mathrm{~mm})$ の疲労強さの減少率は表-4 のと执りであった。

4）実験室内で，鋼材を $3 \%$ 食塩水に浸しながら疲労 試験をすると, 材質, 強さに関係なく一つの疫労強さの 曲線になる。（図-4 破線）これに対して, 陽極的防食法

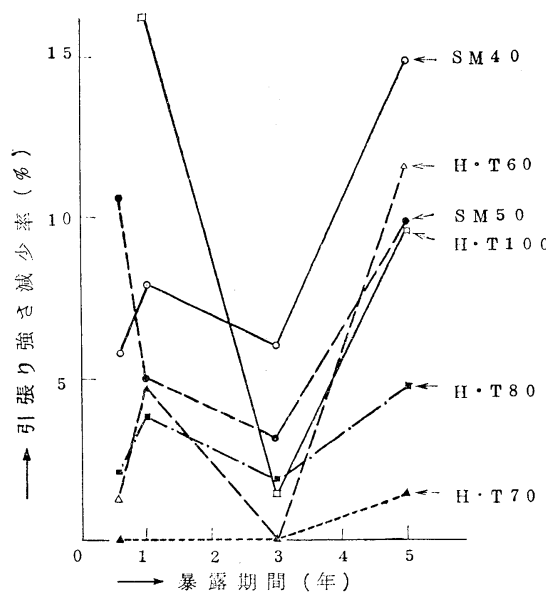

図-3 各種鋼材の引張強さ減少率

表-4 暴露試験片の疲労限 $U \omega$ （鉄道技術研究所による）

\begin{tabular}{|c|c|c|c|c|c|c|c|c|c|}
\hline 期 間 & 暴 露 前 & 3 カ & 月 & 6 カ & 月 & 1 & 年 & 2 & 年 \\
\hline 鋼 & $\begin{array}{c}\sigma_{W} \\
\left(\mathrm{mg} / \mathrm{mm}^{2}\right)\end{array}$ & $\begin{array}{c}\sigma_{W} \\
\left(\mathrm{~kg} / \mathrm{mm}^{2}\right)\end{array}$ & $\left|\begin{array}{|c|}\mid \text { 減少率 } \\
(\%)\end{array}\right|$ & $\begin{array}{c}\sigma_{W} \\
\left(\mathrm{~kg} / \mathrm{mm}^{2}\right)\end{array}$ & $\mid \begin{array}{c}\text { 減少率 } \\
(\%)\end{array}$ & $\begin{array}{c}\sigma_{W} \\
\left(\mathrm{~kg} / \mathrm{mm}^{2}\right)\end{array}$ & $\left|\begin{array}{c}\mid \text { 減少率 } \\
(\%)\end{array}\right|$ & $\begin{array}{c}\sigma_{W} \\
\left(\mathrm{~kg} / \mathrm{mm}^{2}\right)\end{array}$ & $\begin{array}{c}\text { 減少率 } \\
(\%)\end{array}$ \\
\hline SS 41 鋼 & 18.5 & 14.0 & 24 & 14.0 & 24 & 13.0 & 30 & 11.5 & 38 \\
\hline $40 \mathrm{~kg}$ 耐候性鋼 & 24.0 & 18.0 & 25 & 16.0 & 33 & 16.0 & 33 & 15.0 & 37 \\
\hline $50 \mathrm{~kg}$ 酎候性鋼 & 30.0 & 21.5 & 28 & 21.5 & 28 & 19.5 & 35 & 19.5 & 35 \\
\hline $60 \mathrm{~kg}$ 調質高張力鋼 (HT 60) & 34.0 & 22.5 & 34 & 21.5 & 37 & 21.5 & 37 & - & - \\
\hline $80 \mathrm{~kg}$ 調質高張力鋼 (HT 80) & 41.0 & 25.0 & 39 & 24.0 & 41 & 23.0 & 44 & & \\
\hline
\end{tabular}

減少率 $=\frac{\text { 暴露前疲労限一暴露後疲労限 }}{\text { 暴霞 }} \times 100(\%)$ 


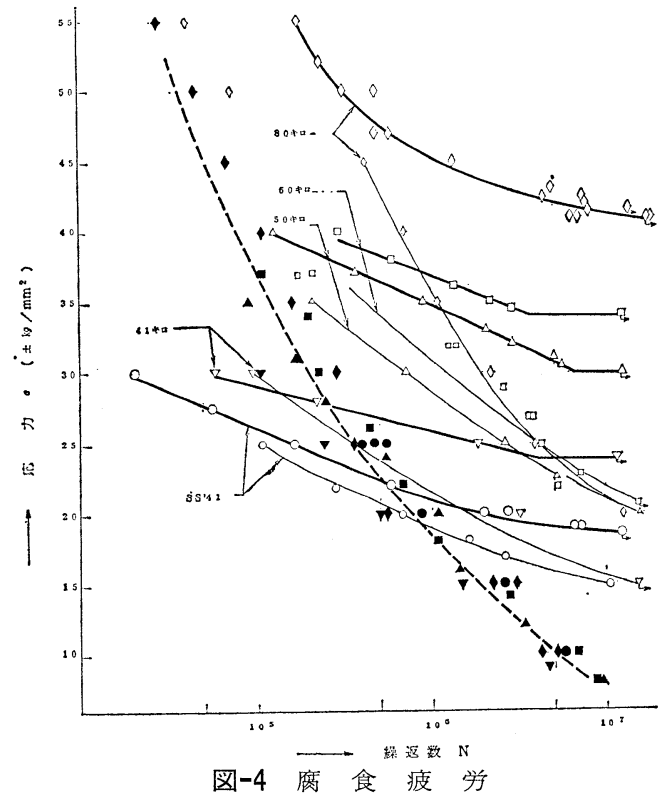

の代表としてクロム酸カリ溶液に浸しながら疲労試験を 行ならと, 鋼材の強さに応じた疲労強さを示す（図-4 細 線)。

5）海峡部橋体には，41キロから 80 キロ鋼までの, 厚さ $9 \mathrm{~mm}$ から $75 \mathrm{~mm}$ までの各種鋼材が混用される。

腐食の点からは不銹鋼が最も望ましい。しかし SM 53 材が原板で約 47,000 円/トンに対して, SUS 27 では約 320,000 円/トンであり経済的にも問題にならない。耐候 性鋼については今後な和検討が続けられるであろう。

吊橋で特徵的なことは，補剛桁には自重による応力が ほとんど働いていない。したがって吊橋補岡桁の80キ 口鋼を用いた部分は, 列車などが通るたびに, 普通の道 路橋の 5～10 倍のヒズミが生じることになる。

6）架橋地点の気温, 日照, 雨量などについては, 特 に加えるまでもないであろう。

ここで鋼体の温度は日照により相当急激に上昇する。 一つの実測例を図-5に示す。

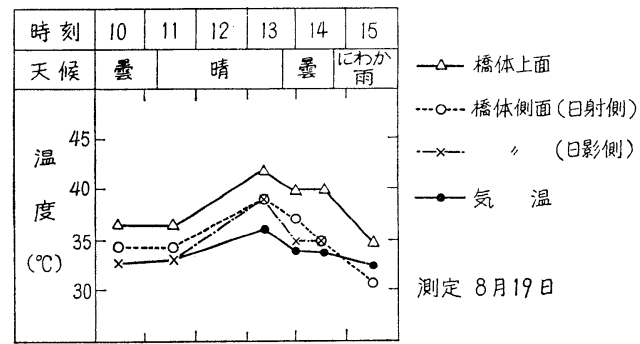

図-5 橋 体 温 度
表-5 日最大 10 分平均風速の超過確率 $(\%)$

\begin{tabular}{c|c|c|c|c}
\hline 高 さ & $10 \mathrm{~m}$ & $30 \mathrm{~m}$ & $50 \mathrm{~m}$ & $80 \mathrm{~m}$ \\
平均風 & & & & \\
\hline $3 \mathrm{~m} / \mathrm{s} \leqq$ & 99 & 100 & 100 & 100 \\
5 " & 89 & 96 & 97 & 99 \\
$7 \prime \prime$ & 55 & 72 & 79 & 84 \\
$10 \prime \prime$ & 19 & 34 & 41 & 53 \\
$15 \prime \prime$ & 2 & 7 & 11 & 16 \\
$20 \prime \prime$ & 0.3 & 0.4 & 3 & 4 \\
$30 \prime \prime$ & 0.1 & 0.2 & 0.3 & 1 \\
$50 \prime \prime$ & & & & 0.1 \\
\hline
\end{tabular}

前にも述べたように架橋地点は諸外国の例に比して, 風がはるかに強い。さらに海峡部橋梁の路面はいずれも 海面上 30 70m の高所にある。風速は高さの $1 / 7$ 乗に ほぼ比例するので, 橋体特に吊橋の塔頂では相当に強い 風速となる。垂水の観測塔での実測值をまとめると表-5 のよらになる。表より路面付近では年間の約半分は $10 \mathrm{~m}$ /秒以上の風が吹いていると推定される。毎年のように くる台風時, 塔頂部では $80 \mathrm{~m} /$ 秒級の風を予想して括か なければならない。

7）吊橋の断面を図-6に示す。図からわかるように鉄 道は橋体(補剛桁)のなかを，自動車は橋体上面を通す。 このため橋体上面にはコンクリート床版あるいは厚さ 12〜20 mm の鋼床版が張られている。床版は幅約 25〜 $30 \mathrm{~m}$ あり, 架設完了後その上面に $150 \sim 200^{\circ} \mathrm{C}$ 程度のア スファルト舗装が施工される。道路タテ桁和よび鉄道タ テ桁が I 型断面である以外はほとんどが口型断面の部材 で組み立られている。各部分はいずれす工場溶接で断面 を組み，現場で各部材を高力ボルトで接合して橋体を形 づくる。前述のように路面すなわち橋体は海面上相当の 高所にあるが，塔下端などは海面上 $10 \mathrm{~m}$ 程度となるた め波しぶきを直接かぶるであろう。

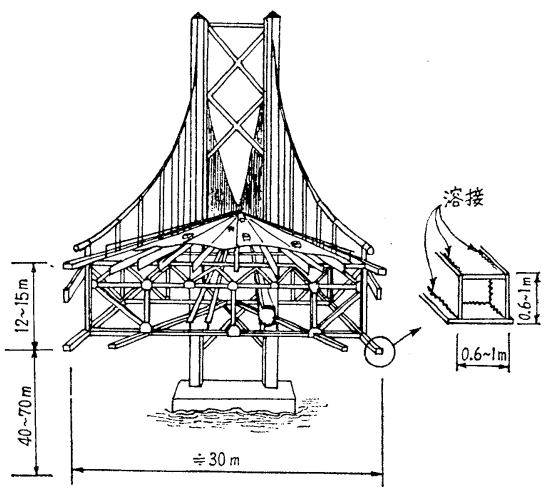

図-6 吊 橋 $の$ 断 面 
表-6 暴露条件の差（イカダ上での暴露）

\begin{tabular}{l|cc|cc}
\hline & 上 & 面 & 下 & 面 \\
\hline 異常を生じたもの & 18個 & \multicolumn{2}{|c}{26 個 } \\
ワレ・ハガ & \multicolumn{1}{|c|}{13} & \multicolumn{2}{c}{6} \\
サ & ビ & 4 & 16
\end{tabular}

注）試料総数 48 個 暴露開始後 17 月目

これまでの経験では溶接部や板の端面からとかくサビ やすい。現地暴露試験でも日光や雨を直接受ける試験片 上面よりもむしろ下面側の方に問題が多くでている。溶 接で型ら゙くり，長手方向数カ所㣂壁の入った口型部材 内面の防食法をどう考学ればよいのであろうか。

工程あるいは作業の単純化，能率化の点からいえばな るべく使用塗装系の種類が少ない方が望ましい。しかし 防食の観点からの諸条件を適確には握した上で，それぞ れに適した塗装系を選択すべきであろう。

8）鋼橋の施工手順を示すと図-7 のようである。

工期としては, 原板ロール後ファブリヶーターで加工

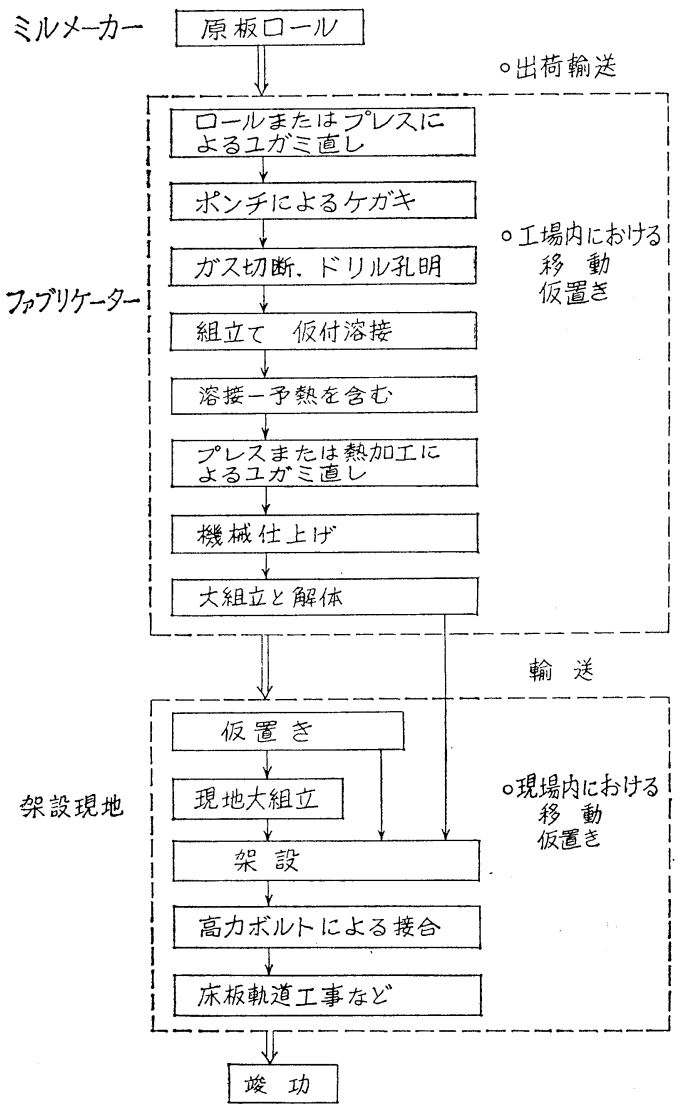

図-7 鋼 橋 の 施 工 手順

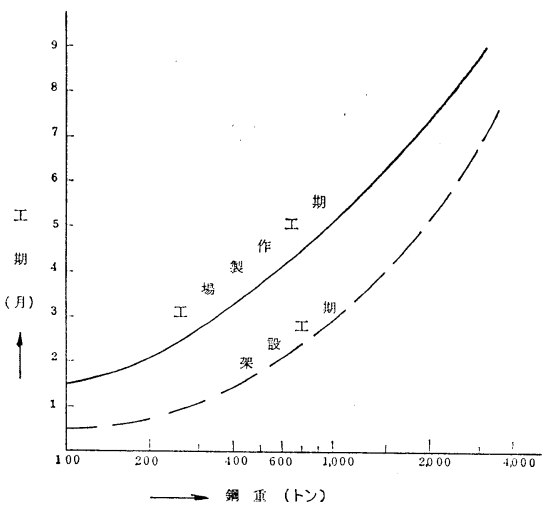

図-8 鋼 橋 の 工 期

(A)

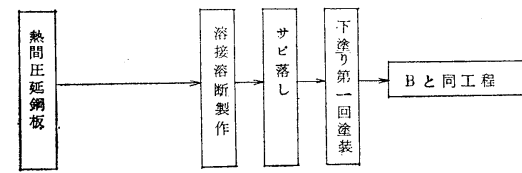

(B)

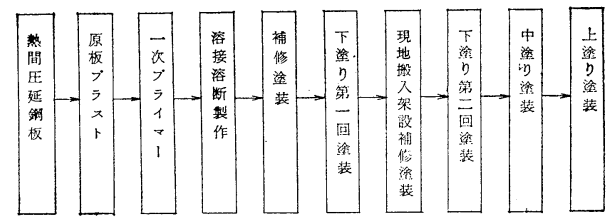

(C)

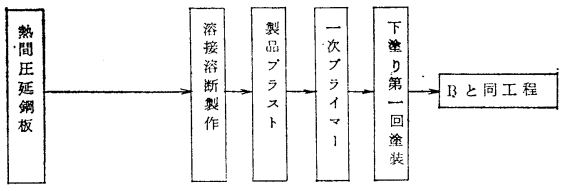

図-9 湮 装 手順

を開始するまでに 1〜2 カ月以上を要する。ファブリケ 一ター内の工期は，これまでの実績から，加工開始後大 組立終了まででまとめると図-8 のようであった。現場架 設の工期は現地の条件によって大幅に変動するが，最初 の部材架設を始めてから最後の高力ボルト締め終了まで の期間を実績值でみると図-8 のようである。海陕部橋梁 のような大規模橋梁の例は少ないが，これらの経験から 塔架設飞 $10 \sim 15$ カ月, $1,000 \mathrm{~m}$ 級の吊橋の補剛桁架設 には 5〜10 カ月, $500 \mathrm{~m}$ 級トラスの架設に洁ぼ 10〜15 カ月を要すると推定される。

図-7 に示す工程のぞの時点に, ぞこで, ぞれまでの防 食作業を組み込むべきであろうか。これまでの普通の橋 梁での標準的な例を図-9 飞示す。図に批いて（B）が現 在の主流であり (A)は現在では例が少なくなってきたと 思われる。

施工管理さえ適切であれば，素地調整にショットブラ 
表-7 塗装下地作製方法の差による塗膜劣化状態

\begin{tabular}{|c|c|c|c|c|c|}
\hline $\begin{array}{l}\text { 試験板 } \\
\text { 番 号 } \\
\end{array}$ & $\begin{array}{l}\text { サビ止め塗料 } \\
\text { の 種 類 }\end{array}$ & サビ 落 し & \multicolumn{3}{|c|}{ 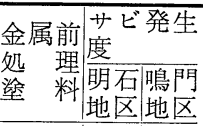 } \\
\hline 3 & $\begin{array}{l}\text { 鉛丹ーアマ= } \\
\text { 油ペイント }\end{array}$ & 黒皮ッキ & 無 & 2 & 2 \\
\hline 4 & " & サンドプラスト & "1 & 6 & 6 \\
\hline 5 & "1 & 11 & 有 & 9 & 7 \\
\hline 6 & $\begin{array}{l}\text { 含鉛サビ止メ } \\
\text { ペイト }\end{array}$ & 黑皮 & 無 & 8 & 9 \\
\hline 7 & "1 & サンドプラスト & "1 & 9 & 10 \\
\hline 8 & "I & $\prime \prime$ & 有 & 10 & 10 \\
\hline
\end{tabular}

注）試験開始後 30 カ月目のデータ

スト, リン酸ピックリング, 塩酸ピックリングいずれの 万法を用いても差支えなく，またこの上にェッチングプ ライマーを塗装することは有効である(表-7)。しかした とえ長暴型でもエッチングプライマーのますで 2 カ月以 上現地暴露をすると, 試験片ですら相当のサビ発生があ った。油性サビ止め塗装のままで現地に置くと層間付着 性が著しく悪かった(表-8)。試みに暴露試験片の塗膜内

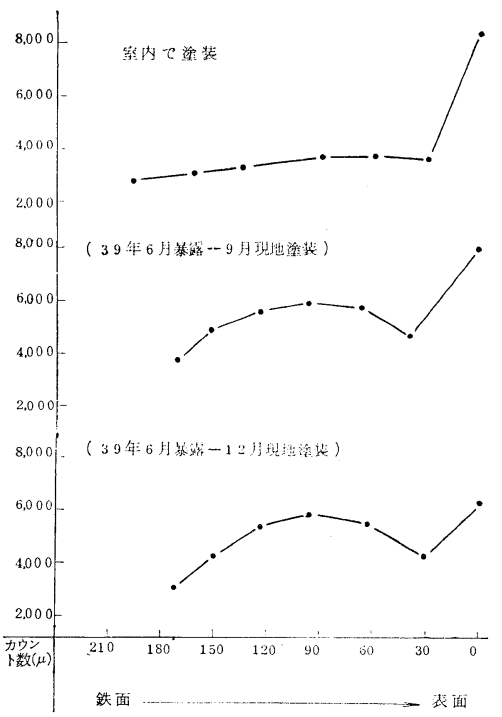

図-10 塗料内部の塩素濃度の分布

部の塩素濃度を測定すると図-10 のようであり，下塗り のまま現地暴露したものには明らかに海塩粒子の影響が.

表-8 暴 露 試 験 結 果

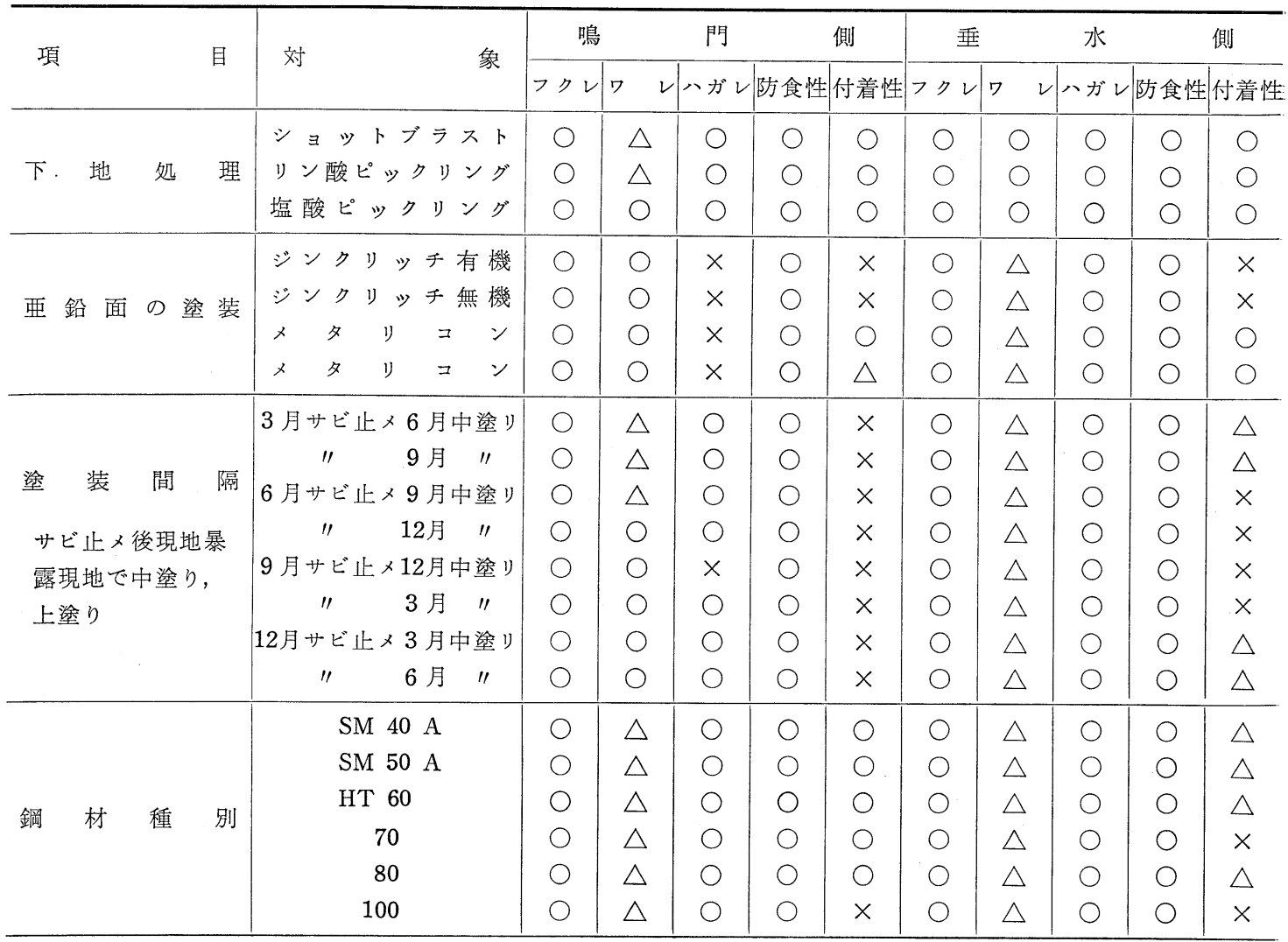


認められた。

海陕部橋梁はこれまでの常識をはるかに越える巨大寸 法である。したがってロールされた鋼板もロール能力の 限界大きさ（最大幅 $4 \mathrm{~m}$, 長さ $25 \mathrm{~m}$, 重量 20 トン程度) が多用されるであろう。ファブリケーターから出荷され る部材としては，塔部材を除き，1部材で幅 $2 \mathrm{~m}$, 高さ $2 \sim 3 \mathrm{~m}$, 長さ $20 \sim 25 \mathrm{~m}$, 重量 $50 \sim 60$ トン程度のものま で予想される。鋼床板はさらに大面積となり，塔部材と なるとさらに大寸法, 大重量となる。現場の架設に当た っては，一般的には部材数が少ない方が望ましい。海上 作業では， $1,000 \sim 2,000$ トン吊りの大型クレーン船が 容易に使用できる。ファブリヶーターの工場能力もまた このクレーン船の能力に合わせて向上しつつあり, 工場 または現場仮組場で $500 〜 1,000$ トン程度に大組及した ものを運搬，架設することも考兄られる。

塗装設備, とくにメッキ槽あるいは機械による溶射な ぞの場合を考劣ると，なるべく部材寸法・重量の小さい らちに作業をした方が望ましい。一方部材寸法重量が小 さいうちに作業するほど, その後の移動加工の度合いが 高くなり,これによるキズはさけられない。

ファブリケーターの工場は大半がいわゆる場地带内 かまたは海岸に位置する。したがっていずれにしてもゴ ミなどを含み塗装環境としては悪い場所である。加えて 部材が大きいだけに敷地の回転率が経済性に大きく影響 する。これらのことから乾燥の速い塗料が望まれてい る。たとえば塩化ゴム系, ビニル系塗料などは著しく乾 燥が速いが，これまでの調査からみると，な打検討の余 地があると思われる。

各種鋼材について，鋼材差を意識しないでショットブ ラストをした上に同一塗装を行なった暴露試験結果は表 -8のようであった。

図-1などからもわかるよらに鋼橋はすべて一品生産 であり, かつ一橋一橋が図-6のように複雑な, 加工度の 高い生産物である。したがって塗装設備るまたこれらの ことを考慮する必要があり，特に自動機械化を計るとき にはこれが問題である。

これらのことから，塗装は単に塗料の面だけからでな く, 塗装作業あるいは鋼橋の製作, 架設作業との関連を 考慮しながら，必要な施工基準を設定すべきであらう。

9）有名なゴールデンダート橋は 1937 年飞竣功して いる。トラス橋として世界第一位のケベック橋は 1917 年に, 第二位のフォース鉄道橋は 1890 年に竣功して, 今な抢その使命を果たしていると聞く。これらからみて も建設費の大きい長大橋は 100 年程度の寿命は考兄て特 くべきであろう。しかも橋は船舶と異なり塗装以外の要
因で定期整備を行ならことは考兄ていない。建物と異な るのはすべての部材が力を受持つ構造部材であり, 部分 的な補修取り替劣を行なら機会も少ない。

一方塗装の寿命はど程度であろらか。周知のよらに 塗装費, 特に塗り替兄塗装の費用の大きな部分は塗料費 以外の足場費などを含んだ叙装作業費である。したがっ て若し若戸橋のように 3 年程度で塗り替光が必要であれ ばむしろ恒久的な足場などの設備, あるいは作業チーム を置く方が望ましくなる。今後ますます強化されるであ ろういわゆる職人の不足, 労働安全性の向上の点からも しっかりした設備は必然的であろうし，またこれだけの 大きな構造物であるから，比較的早い時期に局部的な補 修が必要となるものだと考皇た方がむしろ妥当であるら。 近年橋梁も重塗装化の方向にある。たしか汇金属被覆 は有効であり，たとえば始めからキズをつけて現地に暴 露したのち調べた結果からみても亜鉛系の下地の上に塗 装を行なったるのはより良い結果を得ている。しかしそ の被覆金属の寿命については, JIS H 8300 あるいは JIS 9301 の解説に示されたような值であっても橋の寿命よ りはるかに短い。また上記規格に示されているように， これらの金属被覆はその上に何らかの塗装をすることが 望ましい。とすればこれら金属被覆上に適合した塗料は 何であろらか。暴露試験結果（表-8）からも相当問題で あろうと思われる。さらに作業中避けられないであろう と思われるキズの補修あるいは塗り替兄時に金属被覆の 処置をどう考えるべきであろうか。

一体橋梁の塗装系をどのような考光方で巽択すべきで あらうか。美観維持の点, 補修, 塗り替えなどを考兄合 わせて, むしろ貴重な初期投資額と建設工期を減少させ るといら考方方もり得るよらに思光る。

いうまでもなく橋梁もまたメインテナンスフリーが最 も望ましい。

各種塗料, あるいは塗装系の寿命とその判定, 塗り替 光時の施工基準, 塗装作業用設備, これらを含めた塗装 費用などの明確化が望まれる。

10）塗料の最近の進歩は著しい。一方塗料の試験方法 として, 現在では現地暴露試験のほかに促進試験とし て, ウエザオメーター, あるいは塩水噴霧試験などが行 なわれているが，これら促進試験は現地暴露の結果と対 比すると必ずしも有効であるとはいい難い。

新しい墅料に対して速やかに適確な評価を与兄ること のできる試験法の開発が望まれる。

\section{あ とがき}

本文では本四架橋の現況とその塗装の問題点について 
表-9 暴露 試 験 との 比較

\begin{tabular}{|c|c|c|c|c|c|c|c|c|c|c|}
\hline \multirow{2}{*}{$\begin{array}{l}\text { 塩水噴霧試験の成 } \\
\text { 績 }\end{array}$} & \multicolumn{3}{|c|}{ 明 } & \multicolumn{2}{|c|}{ 石 } & \multicolumn{3}{|c|}{ 鳴 } & \multicolumn{2}{|c|}{ 門 } \\
\hline & $\mathrm{A}$ & B & $\mathrm{C}$ & $\mathrm{D}$ & $\mathrm{E}$ & A & B & C & D & $\mathrm{E}$ \\
\hline $\begin{array}{l}\text { 30時間以内に異常 } \\
\text { を生じたもの }\end{array}$ & & & & & 2 & & & & & 3 \\
\hline $\begin{array}{l}100 \text { 時間以内に異 } \\
\text { 常を生じたもの }\end{array}$ & & & 1 & & 4 & & & 1 & & 4 \\
\hline $\begin{array}{l}100 \text { 時間以上異状 } \\
\text { の見られないもの }\end{array}$ & 8 & 6 & 10 & 0 & 1 & 1 & 4 & 17 & 1 & 2 \\
\hline
\end{tabular}

御紹介をした。

塗料に関連して，仕上げ色調の問題が残されている。 それがあまりにる巨大なるがゆ皇に，それが美しい瀬 戸内の島と海を結ぶが㠴壳に，わが娘の花嫁姿に紅をさ す一にる増しての配慮が必要であろう。

本四橋の塗装については，これまで多くの方々のご努 力によって，数多い知見が得られている。しかし実用ま でにはな物多くの問題が残されているといわざるを得な w。

私どもは本四架橋を無事に，しかもより良い姿で完成 させたいと念願しているが，問題はあまりとも大きい。

諸賢の積極的な御検討と, 御提言を颃願いする次第で ある。
末尾ながら本文をまとめるに当たって，佐藤博士の御 忠言を得た。記して謝意としたい。

\section{文献}

1）本州四国連絡架橋調查の概要，建設省土木研究所 刊, (昭和 41 年 10 月).

2）本州四国連絡道路調查概要報告，建設省道路局， 近畿地方建設局刊, (昭和 45 年 3 月).

3）本州四国連絡鉄道吊橋技術調査委員会中間報告 書, 日本鉄道建設公団刊, (昭和 45 年 6 月).

4）本州四国連絡橋の経済効果(中間報告), 建設省道 路局，運輸省鉄道監督局刊，(昭和 45 年 5 月).

5）本州四国建設連絡橋技術調査報告書, 土木学会刊, (昭和 42 年 7 月).

6）本州四国連絡道路の工費工期，建設省道路局刊, (昭和 44 年 7 月).

7）本州四国連絡鉄道，道路併用橋の工事費工期，日 本鉄道建設公団刊, (昭和 43 年 2 月).

8）今井注か：「海陕連絡鉄道橋の叙装」, 鉄道技研報, No. 422, (1964).

9）佐藤注か:「海洋環境の橋りょ5の防錆淕装」鉄道 技研報, No.771，(1971).

10）本州四国連絡橋用塗料大気暴露試駼報告, 土木研 究所資料, No. 447, (昭和 44 年 3 月).

11）森本：金属材料, 10, [9]，（1965）.

12）国広：「耐候性鋼材の大気ばく万調查」，土木技術 資料. 11，[10]，(1969).

\section{色 材 協 会 誌 Vol. 45 No. 11 (予告)}

総説

水溶液中に扔ける第一鉄イオン空気酸化反応 北海道大学 田 村 紘基他

報 文

顔料一水分散系の研究（第 3 報） 近畿大学 桑 原 利秀他 塗膜の加工性汇関する研究（II） 塗膜の伸びに対する付着力の影響. 大日本塗料(株) 牧 島 博 他

\section{テーマ資料}

ピグメントレジンカラ 東洋インキ製造(株) 天満屋 恵 美 非水分散系の物理化学 岡山大学 田 里 伊佐雄 プラスチブルに関する最近の話題. 日本ゼオン（株）神 保 康太郎

\section{色材サロン}

「私の失敗談」 東京大学 岩 倉 義 男 